The Scream of the Young Burrowing Owl sounds like the Warning of the Rattlesnake

WHILE working upon the tertiary beds of the plains east of the Rocky Mountains recently, I bad numerous op. portunities of making observations on the habits of those peculiar creatures the Burrowing Owls (Speotyto hypogaea). Among others made at the time is one relating to the extraordinary similarity between the sound of the cry of the young owl when disturbed, and that of the warning of the Rattlesnake (Crotalus confluentus), which I do not find to have been noticed by ornithologists. My attention was first called to the peculiar likeness by my friend, Dr. V. T. McGillicuddy, who had in his possession a couple of owlets nearly as large as the adults. The capture of a number of both snakes and birds enabled me by experiment to determine to what extent one might be deceived by the resemblance. At the distance of a few feet the shrill tremulous scream would deceive persons quite familiar with the sound of the rattling of the Crotalus. When not noticing or thinking of the birds, their cry produced on us the same effect as the sudden springing of the rattle by an angry snake. The experiments left no doubt that the cries produced a similar effect on other animals which unwittingly disturbed young owls. And in this way they led to a consideration of the possible benefit of this close resemblance, or, as it might be called by some, mimicry. As you know, the birds are fond of the deserted holes of different burrowing animals, especially so of those of various Spermophiles or Prairie Squirrels. They are common in and about colonies of the so-called "Prairie Dogs" (Cynomys ludovicianus), where they take possession of vacant burrows, and sometimes even of those in use, souner orlater dispossessing the rightful owners, as the dogs seem disinclined to bring eyes and nos as into contact with the sharp beaks and claws in the passages however familiar they may be with the birds around the months of the $\mathrm{dwellings.} \mathrm{In} \mathrm{the} \mathrm{same} \mathrm{localities} \mathrm{the} \mathrm{snakes} \mathrm{are} \mathrm{numerous,} \mathrm{and} \mathrm{the}$ squirrels form a considerable portion of their prey. Naturally enough the rodents-as also the weasels, foxes, and coyotes (Canis latrans)-dread the fangs and venom, and recognise and profit by the warning. May it not be that the peculiar protest or scream of the young owl, by its resemblance to the dangersignal, insures safety by preventing the approach of the mammals, and, possibly, of the dull-eared snakes themselves? The scream of the old bird is rather more hoarse and somewhat less like the shrilling of the serpent. On ordinary occasions, the note of this owl is a cackling or chuckling chatter or laugh, varied with what seem very much like imitations of the barking and squealing of the squirrels. When caught, it gives utterance to the hoarse, long-drawn, rattling scream. The owlets ate greedily of fresh meat, stopping to utter their strange cry of alarm at every attempt to approach them. In behaviour the adults were similar, but much less tractable. One, which had his wing broken, was allowed the freedom of the camp, and usually he stowed himself under the waggon. A halt in a "dog-town" one day brought him near one of the holes, which after a time he discovered. At once his soldierly walk quickened; it became a quick step as he neared the opening. Chuckling to himself, down into the darkness he plunged, and that was the last we saw of him.

Cambridge, Mass., U.S.A., December 3

\section{Fertilisation of the Common Speedwell}

IF Mr. Ransom will refer again to my letter, he will see that it was written in o:der to draw attention to the adapiation of the flower for cross-fertilisation, and not especially to the fact that Diptera in settling upon it, draw down the stamens. This latter, if we consider the close attention paid of late years to the commoner Eurjpean wild flower; has in all probability been frequently observed before. As I have not seen Schenck's hand. book, I would be glad if Mr. Ransom will quote the passage to which he refers. On looking at my note-book I find that not only $\nu$. officinalis, but also $V$. Chamoedrys and $V$. Beccabunga are shown as fertilised in the same manner. May I suggest that the separation of the stamens, and the difference of inctination between stamens and pistil, have been brought about in order to prevent self-fertilisation? The losseness of the corolla would then, in such a flower as $V$. Chamodrys, bring the anthers to a level with the stigma when an insect alighted upon it, and would thus promote cross-fertilisation. From want of $\mathrm{m}$ ore extended o'servations, however, I could not say what would happen in the case of a proterogynous species, or of such a flower as $V$. spicata. In reply to Mr. Ransom, I may add that I have nowhere stated $V$. officinalis to possess larger flowers than $V$. hedercefolia, and that Mr. Darwin " Cross and Self-fertilisation," p. 369 ), in a brief reference to the genus, simply states that $V$. agrestis is self-fertilising, and mentions species of Syrphidæ as visiting the flowers of $V$. hederafolia and $V$. officinalis.

The Owens College, Manchester, December I 5

\section{Complementary Colours at the Falls of Niagara}

IF Mr. Cross, whose letter on the above subject appears in Nature (vol, xxvli. p. 150), will make what is for him a very short excursion from Boston to Niagara, he will see a very perfect and permanent illustration of contrast-colours. In the American fall, the pure, green, even sheet of water is "trimmed," as it were, at regular intervals by broad bands of foam, which although, of course, really white, appear of a delicate rose-pink hue. I noticed, and "made a note of this" ten years ago, and again this year. The effect heightens the beauty of the beautiful fall, and I am surprised that no poet has made capital out of it. I should like to call attention to the rapidity with which the Canadian fall is deepening its horse-shoe. An immense mass broke off near the middle of the curve in October, 1874 (many windows in the adjacent museum were broken by the concussion), and altogether the fall has receded twenty-four feet in ten years.

Eton College, December 15

H. G. MADAN

\section{DUMAS}

THE following is a translation of the addresses delivered in the Paris Academy of Sciences on the 4th inst., on occasion of a commemorative medal being presented to $M$. Dumas :-

'The President, M. Jamin, said : Gentlemen and dear Fellow-Members : The Academy considers it a duty to celebrate the golden wedding of those fellow-members who have honoured it during half a century, a duty which is always dear to us, but to-day is dearer than ever; for M. Dumas now completes his fiftieth Academic year. You have had prepared, by an able artist, a medal which happily recalls his features, and must perpetuate them; it bears on the back this inscription:

\section{A M. DUMAS}

SES CONFRìres, SES ÉLÈES, SES AMIS, SES ADMIRATEURS.

I have nothing to add, except that it is not all his admirers, all his friends, all his scholars, but only those who sit here; the Academy has not been willing to share with any stranger the duty of a homage which it has exclusively reserved to itself. I have the honour to offer in your name, with respect, to our illustrious and venerated fellow-member, this token of our affection and of our gratitude.

My dear Teacher: If you will carry back your thoughts to the commencement of your career, you may well be content with your lot and with yourself. When twentytwo years of age, you were at Geneva; you began with Prevost, by discoveries that are still celebrated in physiology, on the urea, on the blood, and on generation. From that moment your name was known, and you acquired confidence in yourself. Then you perceived two things: the first, that physiology must be built upon chemistry, that chemistry was not made, and that it was necessary to make it; the second, that Geneva was not a large enough theatre for your projects. And so you came to Paris, having no other wealth than yourself, than your courage, than a programme resolutely determined, than the will to fulfil it, than confidence, still unconscious of the future that was promised you. Now the time has advanced, your dreams have been realised, your hopes exceeded, and you have reached the highest degree of glory a savant can conceive. Like Franklin, you may 